\title{
Medical resilience and morality: a survey study on the opinions and actions of exemplary family physicians
}

Roger Ruiz Moral ${ }^{1,2^{*}}$, Diana Monge Martín ${ }^{1}$, Cristina Garcia de Leonardo ${ }^{1}$, Santiago Alvarez Montero and Fernando Caballero Martínez ${ }^{1}$

\begin{abstract}
Background: Studies conducted to understand how family doctors develop resilience and deal with the challenges posed by work-related stress, usually have focused on identifying the elements that generate resilience from psychological perspectives and their impact on coping strategies. Few have explored the role that personal qualities and values that traditionally motivate family physicians can play as drivers of well-being and resilience.

Objectives: To explore attributes that exemplary family physicians (EFP) consider important for their work and the elements that, for them, are source of gratification and resources in the face of the adversities they encounter in their practice.

Methods: This is an exploratory study carried out by online survey. Eighty six doctors regarded as exemplary by their colleagues answered 7 close and 4 open-ended questions that explored their job satisfaction, the elements of their work that reward them, the difficulties and problems they usually encounter, the resources they use to cope with those problems, and the personal qualities they consider central to their work. Four researchers conducted a thematic (deductive and inductive) analysis of the free text responses received. Based on the results obtained, and through an iterative discussion process, the researchers proposed an integrated set of qualities at the core of their professionalism.

Results: $88.4 \%$ (76) of the doctors said they were satisfied with their work. However, they face problems (202 comments), including demanding patients, insensitive managers with unshared interests/care goals, excessive paperwork, work overload, or time pressures. Sources of gratification point to personal identity; clinical, relational, and collaborative efficiency; a holistic and comprehensive practice (centred on individuals); and a continuous search for excellence (149) and the root of their resources (135). These elements, in turn, corresponded to the attributes considered essential for the practice of family medicine (131).

Conclusions: For EFPs, certain professional values give meaning to their clinical practice and are a source of wellbeing and resources. This central focus on professional values and qualities can help for better understand the burnout nature and expand the type of action that promotes resilience. Further studies using a less structured qualitative research will be needed to confirm/expand these results.
\end{abstract}

Keywords: Burnout, Resilience, Professionalism, Medical values, Qualitative research, Medical ethics, Family medicine

*Correspondence: r.ruiz.prof@ufv.es

${ }^{2}$ Instituto Maimónides de Investigación Biomédica de Córdoba (IMIBIC),

Córdoba University, Córdoba, Spain

Full list of author information is available at the end of the article original author(s) and the source, provide a link to the Creative Commons licence, and indicate if changes were made. The images or other third party material in this article are included in the article's Creative Commons licence, unless indicated otherwise in a credit line to the material. If material is not included in the article's Creative Commons licence and your intended use is not permitted by statutory regulation or exceeds the permitted use, you will need to obtain permission directly from the copyright holder. To view a copy of this licence, visit http://creativecommons.org/licenses/by/4.0/. The Creative Commons Public Domain Dedication waiver (http://creativeco $\mathrm{mmons}$.org/publicdomain/zero/1.0/) applies to the data made available in this article, unless otherwise stated in a credit line to the data. 


\section{Introduction}

Traditionally, certain values such as kindness, caring, good communication and interpersonal relationships, availability and accessibility, continuity of care, compassion, honesty, trust, and commitment to people, have been considered the essence of family medicine (FM). In these lies much of the value that society attaches to this specialty, and their relevance can be seen in the definition that WONCA Europe provides for this profession, where they are included as the cornerstones of clinical practice [1]. Some of these personal and specialty attributes have been related to patient satisfaction and positive health outcomes [2], and nowadays family doctors themselves stress their importance and their commitment to developing and respecting them $[3,4]$.

However, the practice of FM has changed a great deal in recent years. Most Western governments have pursued "neo-liberal" health policies $[5,6]$, commodifying the healthcare of many public health systems to make it an increasingly "competitive market" [7]. As a result, priority has been given to employee productivity and flexibility, which has led to an increase in job insecurity $[8,9]$, workload and unpaid overtime [10] and a reduction in the autonomy of the doctor [11], while doctors are expected to continue offering quality with fewer resources $[8,12]$. At the same time, there have also been cultural changes, doctors in FM have seen an increase in patient demand and experience $[9,13]$, as well as new technologies for administering and evaluating the care they provide [11]. This has meant that family doctors have to cope with very demanding cognitive and emotional environments with high workloads and a great deal of dedication, and a large number of them are not satisfied, in particular with working conditions (remuneration, task management) but also with professional acceptance and social recognition $[12,14]$. Burnout syndrome is a description (not a clinical diagnosis) of the degree of distress, emotional exhaustion, depersonalisation, and a sense of low personal achievement caused largely by these work-related stressors [15]. The numbers of doctors suffering from this in Europe vary from one in three to one in five, depending on the country [16].

In this hostile work environment, family doctors struggle to preserve professional attributes and values, and although many cope successfully with this situation [17], others perceive these as being inevitably eroded. The burnout can also be considered a physical and mental health response to this professional and personal "disappointment"; in certain situations, the doctor is unable to achieve or develop their mission or vocation as a professional [18]. This reflects a loss of the sense of being doctors, which reflects the kind of "moral injury" suffered by so many. The term "moral injury" comes from military psychology and refers to psychological trauma [19]. Moral injury occurs when there has been a betrayal of "what is right", committed either by a person with legitimate authority (the profession), or by oneself; in a high-risk situation [20]. Moral injury can deteriorate character, affect confidence, increase despair, and heighten the risk of suicide and interpersonal violence, thus matching the effects described for medical burnout [15] and highlighting the practical significance of damaging one's values.

Interest in understanding the factors that influence a physician's well-being has increased in parallel with the recognition of increased physician burnout and its effects on the quality of the healthcare provided by resilient physicians [21]. Most studies have focused on identifying these factors from the psychological perspective and the impact they have on physical and mental indicators of burnout; however, very little attention has yet been paid to the ethical or "moral injury" incurred and the impact on a doctor's attributes and values. This study intends to do so from a positive perspective, exploring the attributes or qualities that family physicians consider important today, and the role that these play in a practice that is healthy (effective and rewarding) for the doctors themselves. To this end, we have assumed that doctors who are considered exemplary by their colleagues are the repositories of these values and reflect them in their convictions and practice. Our intention is to carry out a first approach study to explore what these attributes or values are and to what extent they are a source of gratification and resources in the face of the adversities that these doctors typically encounter during the course of their work. This will allow us to gauge the validity and role of the attributes themselves as a source of gratification for the physician.

The objectives of this study were, therefore: 1) to identify the aspects that, in the opinion of doctors that are considered to be exemplary, a family doctor should cultivate so that their work is rewarding and effective; 2) to identify their sources of gratification in daily practice; 3 ) to detect the difficulties they experience and the nature of the resources they tend to use to confront these difficulties; and 4) as an additional objective, to identify those attributes and/or qualities detected in the professional profile of these physicians and to explore their coherence and relevance as useful indicators for developing resilience and clinical effectiveness in family doctors.

\section{Methods}

This is considered as a preliminary study conducted by means of an online survey with close and open-ended questions. 


\section{Sample}

We sought out "exemplary physicians", in other words, doctors widely recognised by their peers for their extensive knowledge, ("epistemic" experience) and/or the quality of their practice ("performative" experience) [22]. The following concept of "exemplary physician" was offered for the purposes of the study [23]: "A clinical doctor who is a model for us or for trainees (residents and students), meaning that they are considered a professional worthy of imitation not only for their medical and technical knowledge but also for the quality of their clinical practice, and at the same time for their humanity in dealing with patients and families, their wisdom in general, and their constructive and collaborative spirit towards patients and colleagues". According to this definition, this type of physician may better reflect both the practical approaches and the values of family medicine than others. To select these doctors, using formal and informal networks, we identified a sample of 50 people responsible for training residents, representatives of residents and students and scientific society working groups and in specific geographical areas of the country (Madrid, Andalucía, Castilla, Basque Country and Galicia). They were asked to nominate the largest number of doctors in their sphere that they considered "exemplary" according to the criteria established. Using "snowball" sampling [24], we obtained a list of 102 doctors that included only those doctors who were nominated more than once. These doctors selected as "exemplary physicians" were considered as the purposive sample, they met the criteria of being currently active or having been active until recently (less than a year ago), with clinical practice being their main professional activity.

\section{Survey}

A survey was used as a data collection method because the study was considered as piloting study, where to collect opinions from a high number of physicians about their present, most of them no sensitives, behaviours, was priorised.

Following principles about how design surveys [25, 26] four authors designed a preliminary survey with eight closed questions to obtain quantitative information related to the clinical context, experience, workload and other non-healthcare responsibilities of the respondents as well as their job satisfaction perception. To explore aspects of job dissatisfaction, strategies used to cope with them and essential features of the work of a family doctor, three open questions were also designed. In order to establish definitive content and response process validity a previous pilot testing study was carried out in a convenience sample made up of primary care physicians and hospitals in the authors' environment [27]. The survey was finally sent online to 76 physicians from Madrid and surroundings, with the additional request to evaluate technical aspects of the survey itself. These were family physicians well known and appreciate for their clinical work and responsabilities but not strictly considered as outstanding physicians as we have defined in this study. A response was obtained from 51 doctors with 23 technical comments on the survey and its different items. Based on these comments and their results, the survey was reworked. Most of the items were rewording and one item, originally close-ended, was finally drafted as a free text question. A final 11-question survey was prepared, involving seven closed questions, with different answer options and four open questions (Additional file 1). Administration details: The survey was sent through an online platform to all those selected. Previously a personal letter was sent to all doctors chosen asking for their consent and explained the main objectives of the study, how much time they should given to complete it and clarifying that all responses would be treated anonymously. A period of 3 weeks was stablished for responding with three remainders sent.

\section{Data analysis}

The quantitative data were subjected to a descriptive statistical analysis. For the analysis of the responses to the free text questions, a qualitative thematic analysis was carried out. The first phase of this qualitative analysis included a deductive approach that established $14(5 ; 5 ; 4)$ main predetermined categories from the existing literature and identified in the results of the pilot study (Table 1).

Subsequently, from the free text, the narratives that provided relevant information related to the main categories were identified. In these narratives, codes and subcodes were identified [28], which were quantified to describe

Table 1 Predeterminated themes for analysis

\begin{tabular}{lll}
\hline Rewarding elements & Dissatisfaction elements & Resources for solving difficulties \\
\hline Service/Helping others & Work overload & Management/Organizational \\
Doctor-patient relationship & Administrative burden & Selfcare activities \\
Whole person care & Management/Organizational issues & Teamwork strategies \\
Teamwork & Patients & Relationships \\
Others/Teaching-researching & Teamwork/colleges & \\
\hline
\end{tabular}



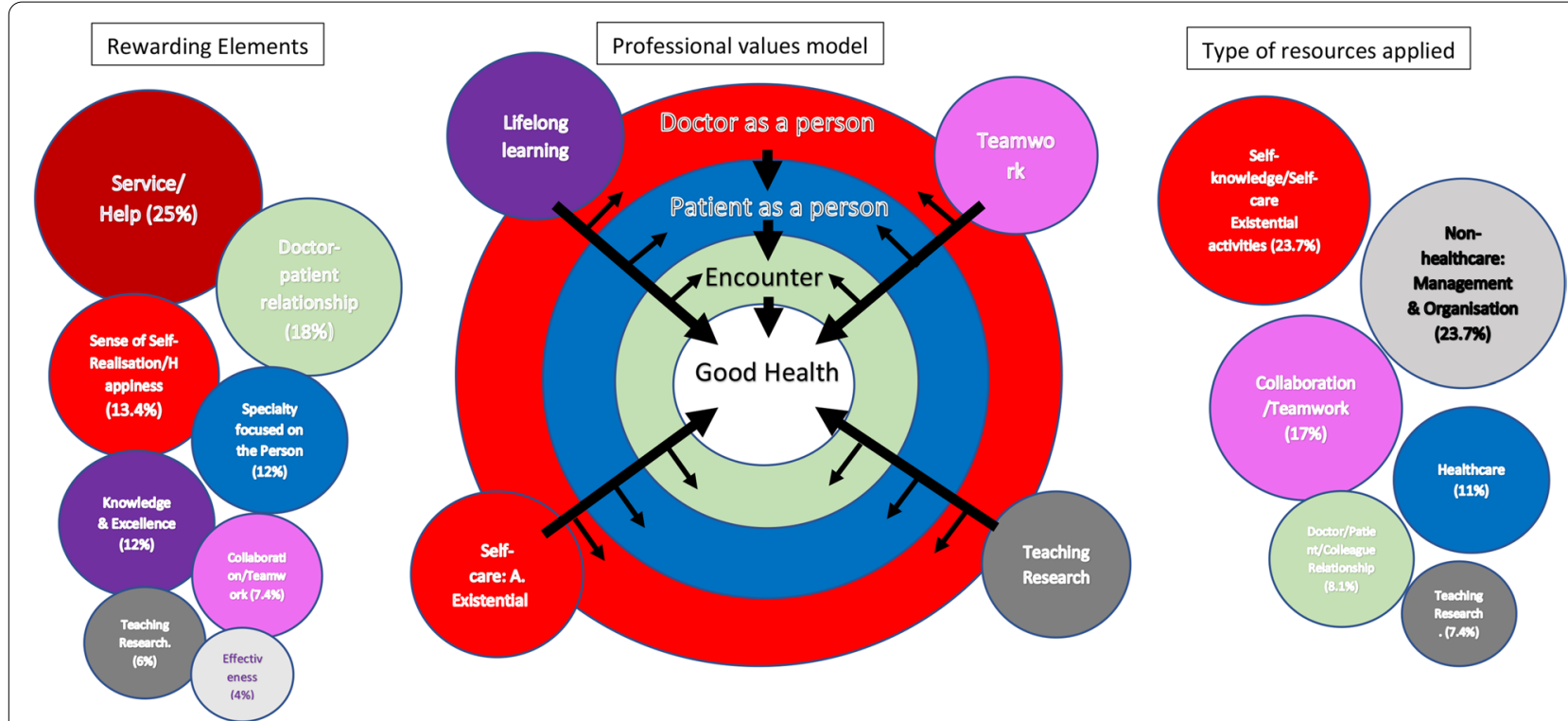

Fig. 1 Integrated model of the personal values required to be a good family physician (central circles)

which main categories appeared more frequently in the narrative responses of the participants. Considering their relevance, some of these new codes were considered as "new main categories". This deductive and inductive quantification and classification of codes to construct and justify the categories can be carried out in qualitative designs [29], and has been used in health sciences. In this study we have included the codes (and narrative fragments) that provided relevant information with the main categories.

Each of the four authors (RRM, SAM, DMM, and CGL) contributed their own codes and subcodes in the transcripts of the response content, with arguments about their interpretations in the most ambiguous points. A discussion process was undertaken supporting and challenging each others reflexivity and assumptions. The key findings are reported in this document. Here we present the strongest emerging themes, using the quotes that best illustrate the shared meaning. For the set of categories identified as essential qualities for a family physician (question 11), each researcher developed their own integrative model that was also discussed in an iterative process that considered existing literature and previous conceptual related theories and frameworks. The model offered in this paper illustrates the consensus and represent a tentative approach (Fig. 1).

\section{Results}

Of the 102 doctors contacted, 86 (84.3\%) replied. Of those, $88.4 \%$ (76) worked in Primary Care and $11.6 \%$ were from Emergency Services (10); 72\% (62) had more than
20 years of work experience and $25.6 \%$ (22) had between 16 and 20 years. $77.9 \%$ (67) of the doctors had, in addition to their clinical duties, other responsibilities, principally teaching students and residents and administrative duties in committees or working groups; $16.3 \%$ (14) had additional non-medical responsibilities. 91.9\% (79) had family responsibilities. $53.5 \%$ (46) of the respondents saw an average of 31-40 patients per day, $16.3 \%$ (14) saw between 21 and 30 patients, and $15.1 \%$ (13) attended more than 40 patients every day.

88.4\% (76) of the physicians stated that they were satisfied with their work both personally and professionally, only 3 (3.5\%) felt unsatisfied, and 7 (8.1\%) were not sure how to respond. Additionally, they were asked if their work was a source of satisfaction and whether they enjoyed it: just over half EFPs $(45 ; 52.3 \%)$ stated that they always or almost always enjoyed it, 36 EFPs (41.9\%) said they typically enjoyed it, one doctor (1.2\%) only enjoyed it sporadically, and $4(4.6 \%)$ stated that they "suffered" from their work, which was a burden.

Tables 2, 3, 4 and 5 list the categories and subcategories identified with examples of the most representative statements received regarding the main reasons why EFPs enjoy their work (the most satisfactory aspects) (question 8; 149 comments), the causes of dissatisfaction or distaste with their work (question 9; 202 comments), the resources that these EFPs routinely employ to attempt to address these difficulties (question 10; 135 comments), and the elements they consider important for effective and rewarding clinical performance (referred to in question 11 as 'advice to beginners'; 131 comments), respectively. 
Table 2 Elements of their clinical performance that exemplary physicians report as rewarding

\begin{tabular}{|c|c|c|}
\hline Main category & Subcategory & Example(s) \\
\hline 1) Service/Help 25\% (37) & $\begin{array}{l}\text { To patients } \\
\text { To colleagues } \\
\text { To trainees }\end{array}$ & $\begin{array}{l}\text { "Being helpful to patients, residents, students and sometimes even } \\
\text { co-workers." }\end{array}$ \\
\hline 2) Doctor-patient relationship 18\% (27) & $\begin{array}{l}\text { With patients } \\
\text { With colleagues } \\
\text { With trainees }\end{array}$ & $\begin{array}{l}\text { "I love dealing with patients and the good therapeutic and per- } \\
\text { sonal relationships I have established over the years"; } \\
\text { "The trust that is established makes it possible to maintain a rela- } \\
\text { tionship that goes beyond mere healthcare." }\end{array}$ \\
\hline 3) Knowledge and excellence seeking 12\% (18) & & "Constant learning with each problem." \\
\hline $\begin{array}{l}\text { 4) Speciality Characteristics and Focus on the } \\
\text { Person } 8 \%(12)\end{array}$ & $\begin{array}{l}\text { Comprehensive care of an individual } \\
\text { Healing vs. curing } \\
\text { Continuity } \\
\text { Longitudinal } \\
\text { Universal } \\
\text { Polyvalence }\end{array}$ & $\begin{array}{l}\text { "Family medicine is about caring for people, and that's why it's the } \\
\text { nicest by far"; } \\
\text { "Helping to improve people's quality of life and supporting them } \\
\text { even though we don't cure them most of the time"; } \\
\text { "Polyvalence: not knowing what is going to come through the door } \\
\text { and the possibility of developing very different skills to deal with the } \\
\text { various health problems"; } \\
\text { "I make health care universal." }\end{array}$ \\
\hline 5) Collaboration/Teamwork 7.4\% (11) & & "I am enriched through the experiences that my colleagues share." \\
\hline 6) Self-fulfilment/Meaning 6.7\% (10) & & $\begin{array}{l}\text { "I see meaning in what I do, even if we don't cure people"; } \\
\text { "It allows me to fulfil myself personally and professionally." }\end{array}$ \\
\hline 7) Happiness 6.7\% (10) & & "I simply enjoy what I do and I can't tell you why." \\
\hline 8) Teaching 6\% (9) & & "I enjoy teaching my residents." \\
\hline 9) Sense of effectiveness 4\% (6) & & $\begin{array}{l}\text { "It's the feeling of a job well done"; } \\
\text { "I enjoy 'good' activity, a well done Medical History, for example. I } \\
\text { could go on, with many things we do well every day." }\end{array}$ \\
\hline 10) Other 6\% (9) & $\begin{array}{l}\text { Recognition } \\
\text { Material aspects } \\
\text { Applying specific techniques } \\
\text { Physical environment }\end{array}$ & $\begin{array}{l}\text { "I feel useful to society because I feel the recognition of my col- } \\
\text { leagues, the recognition of society and because I feel that the } \\
\text { institution where I work understands my problems"; } \\
\text { "I find certain procedures stimulating, like ultrasounds, dermatos- } \\
\text { copy, and so on"; } \\
\text { "It gives me enough money to have a good quality of life" }\end{array}$ \\
\hline
\end{tabular}

Although some responses were briefs with sentences with few words there were many providing copious narrative feedback with high conceptual richness. Among the rewarding aspects, category number 4 includes a sense of holism and integrality that defines the person and seems to be inherent to the specialty and its characteristics; the answers referring to "healing" as something related to those concepts have been included here. Finally, the category "Happiness" (number 7), which includes generic statements of satisfaction, was kept separate. However, to develop the final scheme, it was included in the category "Self-fulfilment/meaning". In the four questions, but especially in those exploring the type of resources used, the answers ranged from generic statements (e.g., "delegate as much as possible" or "deal with situations using constructive criticism", "apply self-care strategies"), to very concrete strategies (e.g., "Working with the 'triap' [Primary Care Triage] model often allows me to address the lack of management involvement in primary care", "If I'm too tired, I'll close the door and relax for a few minutes or go downstairs and find a colleague who is free to chat/ laugh/have a coffee with"). On many occasions, the same doctor, faced with a specific difficulty, e.g., excessive numbers of visits, provided several strategies from different categories, e.g., managing visits (administrative), and communication approaches related to patients, themselves (self-knowledge), and even the team. Conversely, similar strategies could be provided for different challenges. Likewise, a single strategy, e.g., relational, could be employed to address difficulties involving certain types of patients, colleagues, or managers and administrators. Some doctors stated that they had no specific strategies for any particular difficulty. Figure 1 is a graphic illustration of the relationships between the EFPs' ideas of what is important to be a good family physician (central circles in the diagram) and the nature of the practical strategies used: those that provide rewards at work (circles on the left) and the types of resources used to address the issues (circles on the right).

\section{Discussion}

Although these data themselves could not be so "rich" as the narratives expected to get from other qualitative strategies, the analysis was capable of yielding 
Table 3 Main difficulties or aspects of regular work that generate dissatisfaction for exemplary doctors

\begin{tabular}{ll}
\hline Main category & Subcategory \\
\hline 1) Healthcare problems (64) $31.6 \%$ & $\begin{array}{l}\text { Excessive number of patient visits } \\
\text { Insufficient time for care }\end{array}$ \\
& \\
2) The company/healthcare management (32) & $\begin{array}{l}\text { Administrative pressure (re. tasks, objectives) } \\
\text { Management behaviour (arrogance) }\end{array}$ \\
& $\begin{array}{l}\text { Difficult to achieve goals } \\
\text { Interest only in the quantitative at the expense } \\
\text { of the qualitative/human } \\
\text { No/little autonomy for the doctor }\end{array}$
\end{tabular}

3) Excessive bureaucratic burden (20) $9.9 \%$

4) Relationship with colleagues \& team (19) $9.4 \%$

5) Relationship with a certain type of patients (17) $8.4 \%$

6) No/little recognition (14) 6.9\%

7) Work organisation (12) 5.9\%

8) Pay (8) 3.9\%

9) Scarcity of resources (7) $3.4 \%$

10) Other (9) $4.4 \%$
Administrative tasks

Multiple tasks to be performed at the same time Management of sick leave Priority given to protocols and records that are of little use for the patient

\section{Poor coordination with nursing} Impossibility of choosing team Burnt out colleagues

Colleagues at the hospital care level

With a culture of immediacy

No health education

With trivial conditions

No appointment

With certain behaviour (demanding, not very

empathetic, etc.)

In general, towards the specialty

By management regarding the doctor's work

Slow response to certain problems

Lack of flexibility

Software (ICTS)

Specific organisational aspects

Physical spaces

Human resources

Research and teaching (scarce)

Routine

Low resolution capacity

Social problems

Call

Pharmaceutical industry relationship

\section{Example(s)}

"I have to see more patients a day than I am able to do satisfactorily";

"The lack of time to analyse patients properly."

"Pressure from management to fill out forms and protocols to achieve measurable goals";

"Managers at the same level as us treat us arro-

gantly";

"Unrealistic goals, in many cases not adapted to the patient";

"Only financial results matter, not qualitative ones, let alone the human ones";

"Lack of autonomy to manage your own timetable."

"Doing administrative or registration work with little

healthcare value".

"Having to perform multiple tasks simultaneously";

"I don't like the paperwork involved in sick leave";

"The obligation to fill out forms and protocols to achieve measurable goals."

"Poor collaboration with nursing staff";

"Not being able to choose your own team, it's imposed on you";

"Some colleagues are toxic";

"The relationship with some fellow specialists is overly depersonalised, bureaucratised and distant."

"Patients who have a culture of immediacy";

"Poor health education of some patients";

"Visits involving no/trivial conditions";

"Patients who come in again and again without an appointment";

"The few welfare patients who fake symptoms so they can get, and stay on, sick leave."

"Little appreciation of family medicine by healthcare, academic (university) and political institutions";

"The lack of recognition and compensation for those doctors who work well."

"Sometimes solving a patient's problem takes forever due to bureaucracy";

"Difficulty in solving incidents external to our team due to lack of flexibility";

"Computer-related aspects can become hopeless."

"Inadequate pay especially for being on call."

"Physical space is very precarious";

"Lack of personnel, especially for covering things like holidays."

"Research must be done outside working hours";

"Low priority and resources for other activities (teaching, research)";

"The routine sometimes exasperates me";

"I don't like the relationship with the pharmaceutical industry." meaningful qualitative insights. We also ensured rigor by analysing and presenting the results here in tandem with existing literature and conceptual frameworks. Job satisfaction for these EFP seems to be based primarily on the rewards derived, above all, appreciation of the doctors themselves, their medical, relational, and collaborative effectiveness, certain holistic and comprehensive (person-centred) practice characteristics, and a constant search for excellence. The findings clearly show that these physicians are also faced with demanding patients, insensitive managers with interests/healthcare goals they do not share, excessive paperwork, work overloading and time pressures, which are the stressors usually described in the literature and which lead to burnout of other doctors in the same setting [30-32]. To address this, our EFP foster a series of protective practices and attitudes or 


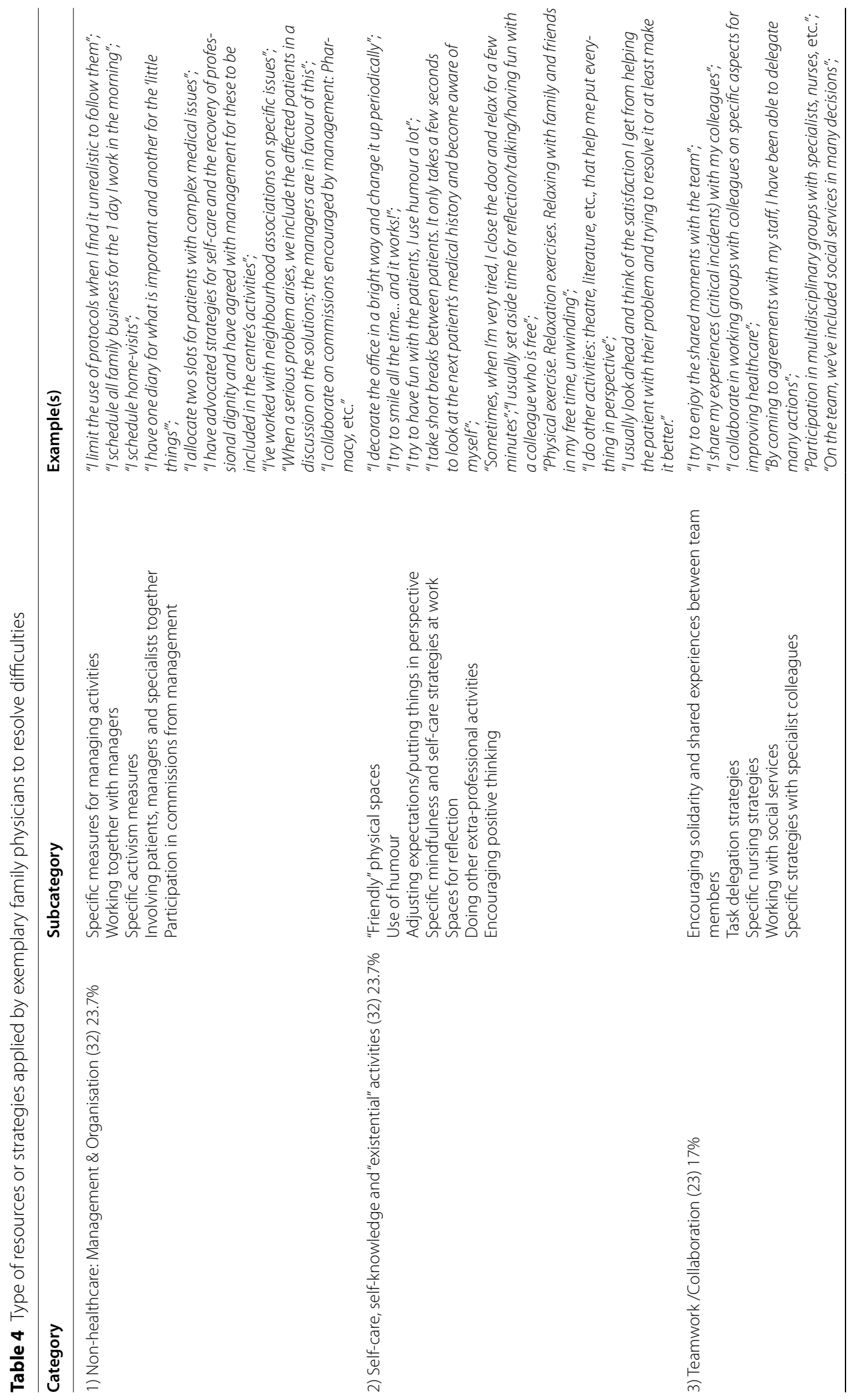




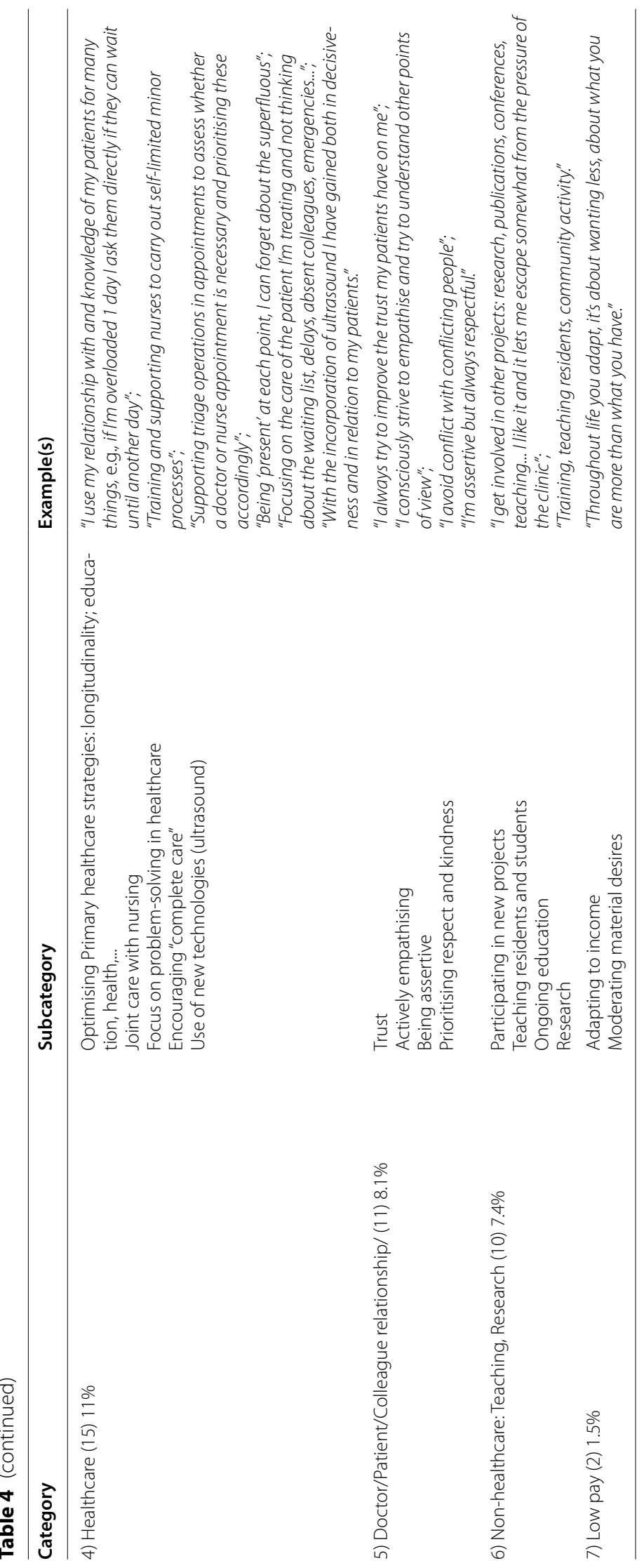


Table 5 Personal attributes that exemplary family physicians believe support effective and rewarding clinical practice in family medicine

\begin{tabular}{|c|c|c|}
\hline Category & Subcategory & Example(s) \\
\hline $\begin{array}{l}\text { 1) The doctor as a person Self-knowledge } \\
\text { Self-care (33) } 25 \%\end{array}$ & $\begin{array}{l}\text { Personal reflection } \\
\text { Critical and flexible thinking } \\
\text { Accepting limits } \\
\text { Managing emotions } \\
\text { Presence } \\
\text { Authenticity } \\
\text { Encouraging certain attitudes }\end{array}$ & $\begin{array}{l}\text { "Taking time to get to know yourself in depth from the start, and at the same } \\
\text { time taking care of yourself for a long journey"; } \\
\text { "Learning about and reflecting on yourself and your role as a family physician"; } \\
\text { "We must learn not to be rigid about anything. No truth is absolute"; } \\
\text { "Knowing how to accept our limits and not blaming ourselves if we do some- } \\
\text { thing wrong (we are also people)"; } \\
\text { "Learning to manage our emotions so we do not harm the clinical relationship"; } \\
\text { "It's about arriving at work, leaving your problems outside the office and mak- } \\
\text { ing the patient see that you care about them and want to help them. To do this, } \\
\text { you must try to be very present in the office"; } \\
\text { "You have to discover your own style and work on it, and be yourself in what } \\
\text { you do"; } \\
\text { "Be curious in every encounter." }\end{array}$ \\
\hline 2) The Patient as a Person (23) 17.5\% & $\begin{array}{l}\text { Dimensions of the person } \\
\text { Context of the person } \\
\text { The doctor as a person }\end{array}$ & $\begin{array}{l}\text { "Don't look at patients as objects of study and a source of learning, but as } \\
\text { people, and try to understand them so that we can help them"; } \\
\text { "Never forget that you will be working with people and that their ailments and } \\
\text { illnesses occur in a personal, family and social context that is very important to } \\
\text { understand and take into account"; } \\
\text { "See the person, with their values and circumstances, behind every clinical } \\
\text { problem"; } \\
\text { "Treat each patient as we would like to be treated ourselves." }\end{array}$ \\
\hline 3) 5) Doctor-Patient relationship (20) $15.2 \%$ & $\begin{array}{l}\text { The relationship } \\
\text { The support } \\
\text { The "medical friendship" }\end{array}$ & $\begin{array}{l}\text { "Realise that the core of our work involves communication and relationships"; } \\
\text { "Be compassionate and try not to judge patients by trying to support them } \\
\text { even if we can't cure them"; } \\
\text { "Always try to empathise with the patients because that will create a 'friendship' } \\
\text { that will also help us when we have difficult moments at work." }\end{array}$ \\
\hline 4) Positivity/Effectiveness (14) 10.7\% & & $\begin{array}{l}\text { "Try to 'always' get something positive out of the day, something beneficial and } \\
\text { comforting, because there is always something; } \\
\text { "It's always essential to be efficient in your work, and maintain this." }\end{array}$ \\
\hline 5) Service/Help (14) 10.7\% & $\begin{array}{l}\text { Usefulness to others } \\
\text { Vocation }\end{array}$ & $\begin{array}{l}\text { "We mustn't lose our goals, our vision, those reasons that led us to study a } \\
\text { humanistic career like medicine, to be at the service of people"; } \\
\text { "Don't lose your vocation to serve." }\end{array}$ \\
\hline $\begin{array}{l}\text { 6) Ongoing learning and } \\
\text { Updating (13) } 9.9 \%\end{array}$ & $\begin{array}{l}\text { Skills } \\
\text { Knowledge }\end{array}$ & $\begin{array}{l}\text { "Don't give up on learning new skills and incorporate these to resolve new } \\
\text { patient problems"; } \\
\text { "You must never stop studying and updating yourself." }\end{array}$ \\
\hline $\begin{array}{l}\text { 7) The doctor as a person Activities with } \\
\text { existential value (12) } 9 \%\end{array}$ & $\begin{array}{l}\text { Recreational } \\
\text { Meditative } \\
\text { Relational }\end{array}$ & $\begin{array}{l}\text { "Read literature, essays, poetry, cultivate friends, make love, eat well and do } \\
\text { sport"; } \\
\text { "Learn not to take work home, to disconnect, fill life with other things: hobbies, } \\
\text { family...; } \\
\text { "Meditate every day." }\end{array}$ \\
\hline 8) Collaboration/Teamwork (10) 7.6\% & & $\begin{array}{l}\text { "Always try to find a time to interact with your co-workers"; } \\
\text { "Treat your fellow professionals well, like your brothers"; } \\
\text { "Cultivate a good atmosphere in the team because you will reap the rewards." }\end{array}$ \\
\hline 9) Teaching/Research (4) 3\% & & "Get involved in teaching and research." \\
\hline
\end{tabular}

mindsets that coincide with those highlighted in other resilience studies $[17,33-35]$, and which can be included within the same domains as their sources of gratification [4]. The most significant of these are: medical, relational and collaborative effectiveness; efforts to update their knowledge; the need to preserve their personal identity by diversifying their social resources and other fields of interest; and by promoting self-knowledge and maintaining realistic expectations. The results also show a correlation between the nature of these rewarding and resilience-building elements that should be essential to a family physician and which, according to these EFP are defined by a sense of personal identity, where clinical practice takes place in the realm of relationships with the unique people they care for (with a holistic and positive sense of what health is) [36], and where aspects such as the search for excellence, self-care, teamwork, teaching and research contribute to good health to the extent that they simultaneously enrich both the doctors themselves and their patients, as well as enhancing the encounters between them. The graph in Fig. 1 highlights this correlation and proposes a hierarchical approach to these 
"essentials" encompassed within conceptual dimensions (central circle in the figure) of these EFP, which as a whole coincide with the fundamentals of professional identity defined by other authors [37]. The parallelism in the type of attributes identified for the three areas explored increases the coherence of these EFPs' actions, as it demonstrates that they actually implement what they think is important. This highlights the importance of developing these core values within the profession, as a source of well-being for these EFP, but at the same time, it can be intuited that if a physician encounters difficulties developing these, this may generate suffering or "moral injury" in that doctor [20].

From this perspective, we believe that proposals to promote medical resilience can be better understood beyond simple and individual interventions, not only for physicians themselves but also in health management and medical education. Consequently, for doctors, enjoying fulfilling clinical practice and resisting its adversities is especially related to the degree to which they identify with the ultimate objectives represented by the values that define their practice, while not focusing exclusively on subordinate objectives such as making good diagnoses, publishing, earning more money, and so on. This, as some studies have pointed out [17,35], is not only achieved by applying the traditionally proposed measures of protective practices and job gratification, but in many cases requires the doctor to develop a narrative that reflects attitudes and mentalities (mindsets) that prioritise the ultimate and integral sense of healing medicine [36] and the meaning underlying the concepts of person, encounter and relationship [37, 38]. At the employer and health administration level, measures should also be directed at changing the institutional patterns that currently appear to be locked into an increasingly complex and conflicting web of loyalties: towards patients, towards doctors, and towards the managers themselves [39], crippling the resilience of doctors and failing to recognise that caring for them leads to better patient care $[21,40]$. From the "moral injury" perspective, it is clear that many physicians propose [34, 41, 42] the need to include systemic work issues that lead to more respectful treatment of doctors, suppressing autocratic mandates or policies that have a dramatic impact, offering them autonomy and authority in rational decision making, and modifying many of the current quality-of-care indicators, in addition to restoring the weight of opinion of many older physicians or those considered exemplary by their peers, such as the participants in this study. Finally, despite the fact that many educational institutions have recently incorporated this type of initiative into their curricula, with courses and specific teaching activities, it is not sufficient that this kind of action is maintained exclusively at this level. The debate here is not new and is in line with the need for medical educational establishments to profoundly overhaul their medical curricula [43, 44], to limit super-specialisation, introduce generalism, the vision of the community as a focus of work, and the socio-behavioural sciences, among other aspects, and promote selection processes that are not exclusively based on knowledge level, in order to balance the currently dominant biomedical scientific perspective [45] with a more qualitative outlook that includes broader epistemological, anthropological and ethical perspectives adapted to the reality of clinical practice [44].

\section{Limitations}

This study has certain limitations that need to be considered. In particular, the use of an online survey, with some open-ended questions. As we mention previously, although free-text responses are not the best method to produce data rich enough to generate robust, stand-alone insights, when they meet the bar for rigorous research their analysis can generate preliminary understanding and help researchers begin to sketch content areas and to inspire new research questions [46, 47]. In order to strength the credibility and the potential of the survey results we pay special attention to some methodological aspects [46]. So, we ensure that the research questions were focused and appropriate; because the free text questions do not typically provide copious narrative feedback in the allotted space, we offered unrestricted response spaces that in many cases allowed sufficiently wide responses, also by means of a large purposive sample size we tried to ensure the sufficiency of the data in answering the research questions coherently and adequately (saturation). The pilot study allowed us both to refine the survey and the previous conceptualization of the data and their analysis. So, we carried out a thematic analysis combining a deductive and inductive approach: the first type will probably not hold for more complex answers, and the second type might end up in an unsystematic and unstructured list of categories. In the combination the development of a structured categorical system started with some themes based on the main results of the pilot study and on the theory underpinning the research project. The fine-tuning and extension that followed was text based [28]. The various backgrounds of the authors involved in the analysis (communication, physiology, statistics, and clinical practice) enriched the process of the thematic categories and subcategories, and increasing the reliability of the findings. Thus, we think the findings confirm the results of previous burnout and resilience studies, and this contributes to their explanatory power and the plausibility of the perspectives presented in this work. Nevertheless, the future research should 
use a less-structured qualitative approach (such as focus groups or deep interviews). On the quantitative side of the study, the number of physicians included in this purposive sample may be criticized, and particularly why using only EFPs; perhaps a more representative sample of a variety of FPs could have offered a more realistic spectrum of the values that these physicians have, however, our hypothesis considered that for a study that pretends in a preliminary way to approach the higher standards, knowing the opinion of the outstanding doctors could better reflect these standards and the deep essence of the speciality.

\section{Conclusions}

Family doctors who are considered exemplary by their colleagues work in the same environments and encounter the same difficulties as them. These physicians, however, enjoy different aspects of their work and employ strategies to cope with challenges that are similar to those previously described in the literature. This study highlights how similar these sources of gratification and resilience strategies are to the essential attributes they prioritise for doctors practicing family medicine. This research also emphasises the central importance of these core elements as a source of well-being or potential suffering (or moral injury) for a physician and the need for doctors, managers and educators to consider them as a reference for fostering deeper and broader approaches that promote resilience and avoid burnout. However, further studies using a less structured and more comprehensive and in-depth qualitative research will be necessary to confirm and expand these results.

\section{Abbreviations}

EFP: Exemplary family physicians; WONCA: World Organisation of Family Doctors; FM: Family medicine; RRM: Roger Ruiz Moral; SAM: Santiago Alvarez Montero; DMM: Diana Monge Martín; CGL: Cristina García de Leonardo.

\section{Supplementary Information}

The online version contains supplementary material available at https://doi. org/10.1186/s12875-021-01555-0.

Additional file 1. Medical Resilience and Morality SURVEY.

\section{Acknowledgments}

We would like to thank all the family physicians who participated in this study.

\section{Authors' contributions}

RRM designed and managed this study. He contributed to the data collection and analysis and drafted the paper. He is guarantor for the study and paper. SAM, DMM and CGL contributed to data analysis and writing the paper. FCM contributed to the pilot study, strategy for the recruitment of exemplary family physicians, and writing the paper. All authors read and approved the final manuscript

\section{Funding}

This research received no specific financing from funding agencies in the public, commercial, or non-profit sectors.

\section{Availability of data and materials}

The datasets used and analysed during the current study are available from the corresponding author on reasonable request.

\section{Declarations}

\section{Ethics approval and consent to participate}

The UFV Health Sciences Faculty review board (IRB), considered this study congruent to the established ethical and legal requirements, and gave its approval (IRB 2/2021)

Informed consent to participate in the study was obtained from all the survey respondents.

\section{Consent for publication}

Not applicable.

\section{Competing interests}

The authors declare that they have no competing interests.

\section{Author details}

${ }^{1}$ Unidad de Educación Médica, Escuela de Medicina, Universidad Framcisco de Vitoria, Madrid, Spain. ${ }^{2}$ Instituto Maimónides de Investigación Biomédica de Córdoba (IMIBIC), Córdoba University, Córdoba, Spain.

Received: 5 April 2021 Accepted: 22 September 2021

Published online: 25 October 2021

\section{References}

1. WONCA Europe. The European Definition of General Practice/Family Medicine. WONCA Europe 2002. https://www.woncaeurope.org/page/ definition-of-general-practice-family-medicine Accessed 23 Jul 2020.

2. Sans-Corrales M, Pujol-Ribera E, Gené-Badia J, Pasarín-Rua MI, IglesiasPérez B, Casajuana-Brunet J. Family medicine attributes related to satisfaction, health and costs. Fam Pract. 2006;23(3):308-16.

3. Cubaka VK, Dyck C, Dawe R, Alghalyini B, Whalen-Browne M, Cejas G, et al. A global picture of family medicine: the view from a WONCA Storybooth. BMC Fam Pract. 2019;20:129. https://doi.org/10.1186/s12875-019-1017-5.

4. Le Floch B, Bastiaens H, Le Reste JY, Lingner H, Hoffman R, Czachowski $\mathrm{S}$, et al. Which positive factors give general practitioners job satisfaction and make general practice a rewarding career? A European multicentric qualitative research by the European general practice research network. BMC Fam Pract. 2019;20:1-11.

5. Sánchez BM. Hacia el estado del malestar. Neoliberalismo y política sanitaria en España [towards the state of discomfort. Neoliberalism and health policy in Spain] (original in Spanish). Madrid: La Catarata; 1998.

6. Illouz E. Cold intimacies: the making of emotional capitalism. Cambridge: Polity; 2007.

7. Greenhalgh T. Future-proofing relationship-based care: a priority for general practice. Br J Gen Pract. 2014. https://doi.org/10.3399/bjgp14X682357.

8. Sánchez Bayle M. La privatización de la asistencia sanitaria en España. [The privatization of healthcare in Spain] (Original in Spanish). Documento de trabajo 182/2014 Fundación Alternativas, 2013. https://www. fundacionalternativas.org/public/storage/laboratorio_documentos_archi vos/24bb33c2b5a6aca0f1 ea50a199da5de7.pdf Accessed 23 Jul 2020.

9. Baird B, Charles A, Honeyman M, et al. Understanding pressures in general practice. London: King's Fund; 2016.

10. Burchell B, Ladipo D, Wilkinson F. Job insecurity and work intensification. London: Routledge; 2005.

11. Harrison S. Co-optation, commodification and the medical model: governing UK medicine since 1991. Public Adm. 2009;87(2):184-97.

12. Lionis C, Petelos $E$. The impact of the financial crisis on the quality of care in primary care: an issue that requires prompt attention. Qual Prim Care. 2013;21(5):269-73. 
13. Hobbs FD, Bankhead C, Mukhtar T, et al. Clinical workload in UK primary care: a retrospective analysis of 100 million consultations in England, 2007-14. Lancet. 2016:387(10035):2323-30.

14. Sobrequés J, Cebrià J, Segura J, Rodríguez C, García M, Juncosa S. La satisfacción laboral y el desgaste profesional de los médicos de atención primaria. [Job satisfaction and burnout in general practitioners]. (Original in Spanish) Aten Prima. 2003;31:227-33.

15. Maslach C, Schaufeli WB, Leiter MP. Job burnout. Ann Rev Psychol. 2001;52:397-422 Epub 2001/01/10.

16. Soler JK, Yaman $H$, Esteva M, et al. Burnout in European family doctors: the EGPRN study. Fam Pract. 2008;25(4):245-65.

17. Zwack J, Schweitzer J. If every fifth physician is affected by burnout, what about the other four? Resilience strategies of experienced physicians. Acad Med. 2013;88(3):382-9.

18. Halligan A. The first casualty of reform: lost NHS values. Br J Health Manag. 2007;13:288-90.

19. Litz T, Stein N, Delaney E, Lebowitz L, Nash WP, Silva C, et al. Moral injury and moral repair in war veterans: a preliminary model and intervention strategy. Clin Psychol Rev. 2008;29:695-706.

20. Shay J. Moral injury. Psychoanal Psychol. 2014;31(2):182-91. https://doi. org/10.1037/a0036090.

21. Wallace JE, Lemaire JB, Ghali WA. Physician wellness: a missing quality indicator. Lancet. 2009;374(9702):1714-21.

22. Weinstein BD. What is an expert? Theor Med. 1993;14(1):57-73. https:// doi.org/10.1007/BF00993988.

23. Langley GR, Till JE. Exemplary family physicians and consultants: empirical definition of contemporary medical practice. Can Med Ass J. 1989;141(4):301-7.

24. Goodman LA. Snowball sampling. Ann Math Statistics. 1961;32(1):148-70. https://doi.org/10.1214/aoms/1177705148.

25. Artino AR Jr, La Rochelle JS, Dezee KJ, Gehlbach H. Developing questionnaires for educational research: AMEE guide no. 87. Med Teach. 2014;36:463-74

26. Gehlbach $H$, Artino AR Jr. The survey checklist (manifesto). Acad Med. 2018;93:360-6.

27. Ruiz Moral R, Cerro A. What doctors do and think for avoiding "burnout" about their work? A quanti-qualitative study with "exemplary doctors" (original in Spanish). Bull Doctutor Edu Med. 2019; Accessed 22 Mar 2021. https://www.doctutor.es/2019/11/04/que-hacen-y-piensan-sobre-sutrabajo-los-medicos-para-no-quemarse-un-estudio-cuanti-cualitativocon-medicos-ejemplares/.

28. Popping R. Analyzing open-ended questions by means of text analysis procedures. Bull Sociol Methodol/Bull Méthodol Sociol. 2015;128(1):23-39.

29. Miles M, Huberman A, Saldaña J. Qualitative data analysis. A method sourcebook. 3rd ed. Thousand Oaks: Sage; 2013.

30. Molina Siguero A, García Pérez M, Alonso González M, Cecilia CP. Prevalencia de desgaste profesional y psicomorbilidad en médicos de atención primaria de un área sanitaria de Madrid. [Prevalence of professional burnout and psychomorbidity in primary care physicians from a Madrid health district ] (Original in Spanish). Aten Primaria. 2003;31:564-74

31. Vilà Falgueras M, Cruzate Muñoz C, Orfila Pernas F, Creixell Sureda J, González López MP, Davins MJ. Burnout y trabajo en equipo en los profesionales de Atención Primaria. [Burnout and team working in Primary Healthcare proofessionals] (Original in Spanish). Aten Primaria. 2015;47(1):25-31.

32. Párraga Martínez I, González Hidalgo E, Méndez García T, Villarín Castro A y, León Martín AA. Burnout y su relación con el estrés percibido y la satisfacción laboral en profesionales sanitarios de Atención Primaria de una Comunidad Autónoma. [Burnout and its relationship with perceived stress and job satisfaction in primary healthcare professionals in an Autonomous Community] (Original in Spanish). Rev Clin Med Fam. 2018;11(2):51-60.

33. Meldrum H. Exemplary physicians'strategies for avoiding burnout. Health Care Manager. 2010;29:324-31.

34. Hall LH, Johnson J, Jane Heyhoe J, Watt I, Anderson K, O'Connor DB. Strategies to improve general practitioner well-being: findings from a focus group study. Fam Pract. 2018;35:511-6.

35. O'Dowd E, O'Connor P, Lydon S, Mongan O, Connolly F, Diskin C, et al. Stress, coping, and psychological resilience among physicians. BMC Health Serv Res. 2018;18:730.

36. Egnew T. The meaning of healing: transcending suffering. Ann Fam Med. 2005 May;3(3):255-62.

37. Phillips WR, Haynes DG. The domain of family practice: scope, role, and function. Fam Med. 2001;33(4):273-7.

38. Ruiz Moral R. ¿Por qué unos médicos se queman y otros no? Una perspectiva desde la ética [Why do some doctors burned out and others do not? A perspective from ethics] (Original in Spanish). Boletín de Educación Médica Doctutor, 2019, Nov 2. https://www.doctutor.es/2019/ 11/02/porque-unos-medicos-se-queman-y-otros-no-una-perspectivadesde-la-etica/ Accesed 23 Jul 2020.

39. Talbot SG, Dean W. Physicians aren't 'burning out.'They're suffering from moral injury. 2018. https://www.statnews.com/2018/07/26/physiciansnot-burning-out-they-are-suffering-moral-injury/ Accesed 23 Jul 2020.

40. Fahrenkopf AM, Sectish TC, Barger LK, et al. Rates of medication errors among depressed and burnt out residents: prospective cohort study. BMJ. 2008;336(7642):488-91.

41. Cheshire A, Ridge D, Hughes J, Peters D, Panagioti M, Simon C, et al. Influences on GP coping and resilience: a qualitative study in primary care. $\mathrm{Br}$ J Gen Pract. 2017;67(659):e428-e436. https://doi.org/10.3399/bjgp17X690 893.

42. McKinley N, Karayanis PN, Convie L, Clarke M, Kirk SJ, Campbell WJ. Resilience in medical doctors: a systematic review. Postgrad Med J. 2019:136135. https://doi.org/10.1136/postgradmedj-2018-136135.

43. Litva A, Peters S. Exploring barriers to teaching behavioural and social sciences in medical education. Med Educ. 2008:42:309-14.

44. Ruiz MR. La incorporación de las humanidades y ciencias socio-conductuales en la educación médica ¿cuál es el problema y qué se Debe hacer? [incorporating the humanities and socio-behavioral sciences in medical education: what is the problem and what should be done? ] (original in Spanish). Folia Humanistica. 2019;11:65-81. https://doi.org/10.30860/ 0050.

45. Bloom SW. Structure and ideology in medical education: an analysis of resistance to change. J Health Soc Behav. 1988;29:294-306.

46. Tracy SJ. Qualitative quality: eight "big-tent" criteria for excellent qualitative research. Qual Inq. 2010;16(10):837-51.

47. LaDonna KA, Taylor T, Lingard L. Why open-ended survey questions are unlikely to support rigorous qualitative insights. Acad Med. 2018;93(3):347-9. https://doi.org/10.1097/ACM.0000000000002088.

\section{Publisher's Note}

Springer Nature remains neutral with regard to jurisdictional claims in published maps and institutional affiliations. 